\title{
EFFECT OF ASPIRIN ON CUTANEOUS RESPONSE TO THE LOCAL APPLICATION OF AN ESTER OF NICOTINIC ACID
}

\author{
BY \\ LESLIE H. TRUELOVE AND J. J. R. DUTHIE \\ From the Rheumatic Unit, Northern General Hospital, Edinburgh
}

"Trafuril"* is the trade name of a cream con-
taining 5 per cent. by weight of tetrahydrofurfuryl
nicotinic acid ester in a water-miscible base. The
cutaneous reaction which follows the local applica-
tion of this substance has been described by Strehler (1949). It is characterized by the appearance, within 10 to 30 minutes, of erythema usually accompanied by superficial oedema.

Nassim and Banner (1952) made the interesting observation that this response was absent in patients with active rheumatoid arthritis. In less acute cases, a mild erythema only was produced. In those with minimal evidence of activity or in remission, a normal or subnormal response was the rule. The diminished skin reaction in a proportion of patients with rheumatoid disease was subsequently confirmed by Oka (1953), Vaillancourt (1954), and Bartfeld and Hartung (1954). In these reports no mention was made of whether the patients were being treated with aspirin at the time of testing. Leifer and Batterman (1955) could detect no difference between the reactions in a group of patients with rheumatoid arthritis and in a comparable group of patients with a variety of other diseases. The majority of arthritic patients were stated to be receiving salicylates as an analgesic agent.

During an investigation of the effects of aspirin on experimentally-induced erythema, "Trafuril" was applied to the forearm of patients with rheumatoid arthritis who were not taking aspirin. The sub-

- Manufactured by Messrs. Ciba Ltd. sequent reaction was similar to that seen in healthy controls. On the basis of these observations it was decided to study in more detail the effect of aspirin on the reaction to "Trafuril" in normal subjects and in patients with rheumatoid arthritis.

\section{Material and Methods}

Tests were made on healthy hospital staff and on patients in hospital suffering from "definite" rheumatoid arthritis according to the diagnostic criteria proposed by the American Arthritis and Rheumatism Foundation (Ropes, Bennett, Cobb, Jacox, and Jessar, 1956). They were on a basic regimen consisting of rest in bed, splinting of affected joints, and physiotherapy. Initially all were receiving aspirin in doses of 60-80 gr. daily.

The ester was used in the form of the 5 per cent. "Trafuril" cream, or as a 5 per cent. solution in $0.15 \mathrm{M}$ sodium chloride.

Tests were made by applying approximately $120 \mathrm{mg}$. "Trafuril" cream uniformly to an area one inch in diameter on the volar surface of the forearm, or by applying the solution to a similar area of skin.

Reactions were graded as follows:

$$
\begin{aligned}
& \text { 0-No erythema } \\
& \text { 1-Erythema without oedema } \\
& \text { 2-Erythema and oedema }
\end{aligned}
$$

Aspirin was given by mouth in the form of tablets which produced $5 \mathrm{gr}$. calcium aspirin when dissolved in water. Solutions for intradermal injection were prepared by dissolving calcium aspirin in $0.15 \mathrm{M}$ sodium chloride. The pH was adjusted to between 7 and 8 by the addition of $0.1 \mathrm{M}$ sodium hydroxide.

Aspirin and free salicylate in the blood were estimated by the method described by Smith (1951). 


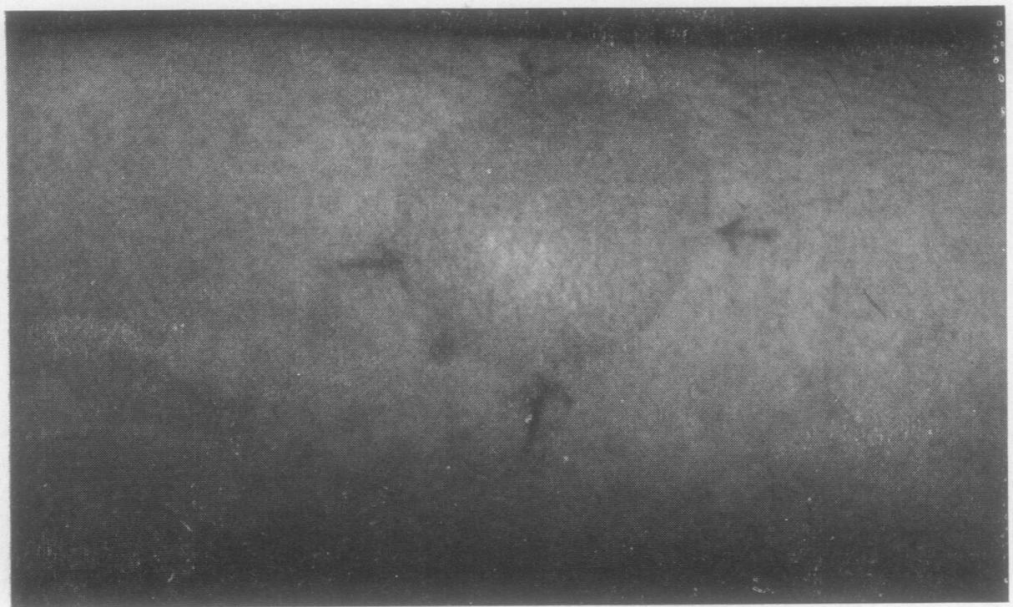

Fig. 1.-Reaction after an application ester-Grade 1.

Fig. 2.- Reaction after an application of ester-Grade 2.

\section{Results}

Characteristics of the Reaction.-Application of "Trafuril" cream to the skin of healthy subjects resulted in the appearance of a punctate erythema within 5 to 10 minutes. The erythema rapidly became confluent and covered an area corresponding exactly to the site of application (Fig. 1). Superficial oedema then developed (Fig. 2), and in most subjects the area became surrounded by a flare. The reaction reached its maximum intensity in half an hour and faded gradually thereafter. The erythema persisted for a further 4 to 5 hours.

Strehler (1949) observed a considerable variation in sensitivity between individuals and this was confirmed. However, the sensitivity of an individual did not vary significantly from day to day. It was therefore considered justifiable to compare the results of testing the same individuals on successive days. Identical results were obtained whether tests were made with the cream or the solution.
Chilling of the skin before application of the "Trafurips resulted in a diminished response, and for this reason experiments were performed at room temperature abo $20^{\circ} \mathrm{C}$.

Effect of Aspirin by Mouth on the Reaction in Norma Subjects. - A series of single tests in normal individuaids showed that a dose of $10 \mathrm{gr}$. calcium aspirin by mou resulted in partial suppression of the reaction wherp "Trafuril" was applied 1 hour later. A proportion $\bar{A}$ subjects in these tests showed erythema arising at the sice of application of the "Trafuril" from 2 to 3 hours late्क. Ten normal subjects were therefore given $10 \mathrm{gr}$. calcium aspirin by mouth and a standard application of the estef was made 1 hour later. The reactions were read aftes half an hour and thereafter hourly for the followirg 5 hours. A control group of ten subjects was similarf tested. The results are illustrated in Fig. 3 (opposite). 


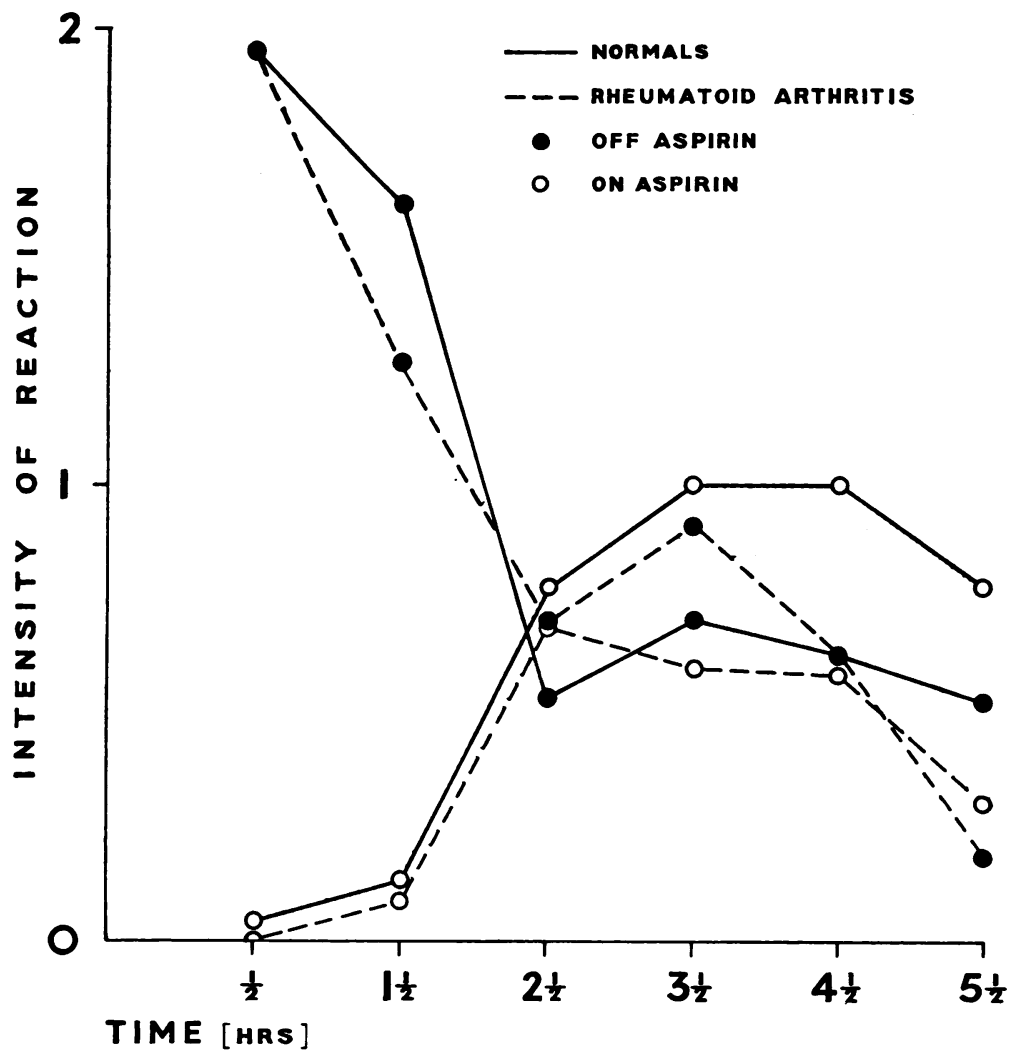

Fig. 3.-Mean response in normal and rheumatoid subjects after a single application of ester.

The greatest difference between the groups was observed half an hour after the application of the ester. At this time the subjects who had been given the aspirin showed pallor or faint blueness at the site of application (Fig. 4, overleaf).

Erythema developed in this area after 2 to 3 hours (Fig. 5, overleaf), and subsequently there was no distinction between the subjects who had been given aspirin and those who had not. The delayed appearance of erythema was not due to excretion of the aspirin as the initial phase of the reaction to the ester re-applied at this stage was still suppressed.

Effect of Aspirin by Mouth on the Reaction in Patients with Rheumatoid Arthritis.-A similar experiment was performed on ten patients with rheumatoid arthritis. Treatment with aspirin was stopped for 3 days before the test; 5 per cent. "Trafuril" cream was used and the reactions recorded as in the previous experiment. The administration of aspirin was then resumed and the tests repeated the following day. The results are shown superimposed on those of the previous experiment in Fig. 3. They do not differ from those recorded in normal subjects.

Oedema was never observed in the delayed type of reaction seen when aspirin had been administered before the test.

Local Effect of Aspirin on Reaction to "Trafuril". $0.1 \mathrm{ml}$. of a solution of calcium aspirin containing $4 \mathrm{mg} . / \mathrm{ml}$. was injected intradermally into the forearm. "Trafuril" cream was applied to the area 1 hour later. When the reaction was read after a further half hour, an area of pallor $20 \mathrm{~mm}$. in diameter was apparent surrounding the site of injection (Fig. 6). This area became erythematous after a further $2 \frac{1}{2}$ hours and was then no longer distinguishable from the surrounding erythema. Injection of $0.1 \mathrm{ml}$. of $0.15 \mathrm{M}$ sodium chloride had no such effect. An injection containing one-tenth of the dose of aspirin produced a rather smaller area of modified response (Fig. 6, overleaf).

Effect of Variations in Dose of Aspirin.-In normal subjects a single dose of $10 \mathrm{gr}$. calcium aspirin by mouth was always sufficient to cause suppression of the immediate reaction to "Trafuril". An attempt was made to determine the lowest dose of aspirin sufficient to achieve this effect and to correlate this dose with the levels of aspirin and free salicylate in the blood. Thirteen normal subjects were given doses of calcium aspirin by 


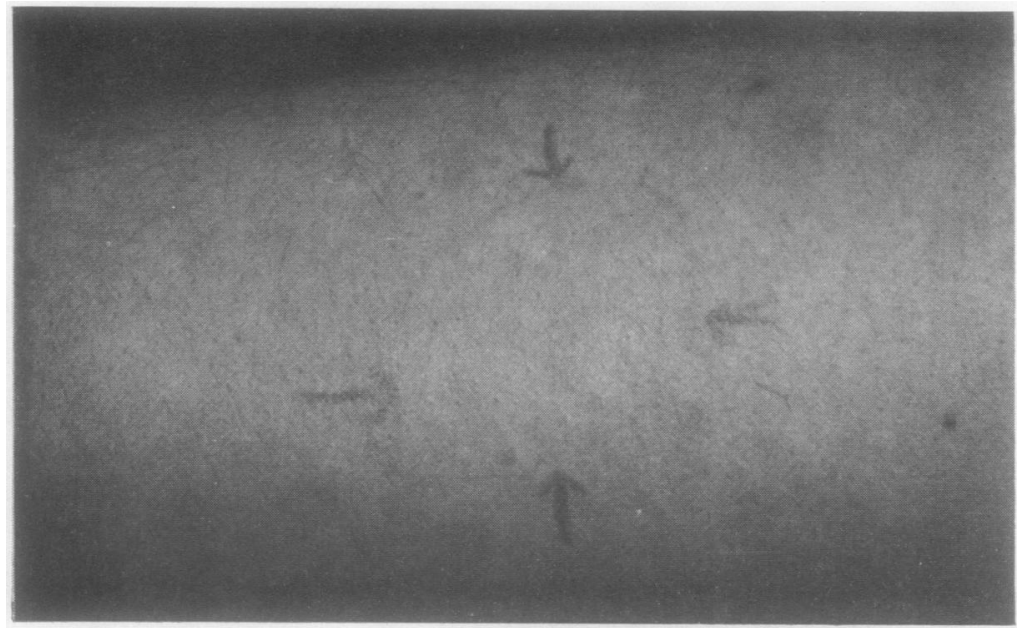

Fig. 4.-Modified reaction after 10 aspirin by mouth.

Fig. 5.-Delayed erythema. The same site as Fig. 4, 3 hours later.

Fig. 6.-Local effect of aspirin on re음 action to "Trafuril". 
mouth varying from 2.5 to $10 \mathrm{gr}$. and were tested at varying times later. The results showed that suppression of the early phase of the reaction could be complete even when aspirin or free salicylate could not be detected in the blood and that this effect persisted for 24 hours or longer.

\section{Discussion}

The response to "Trafuril" applied to the skin of normal subjects has been described. Patients with rheumatoid arthritis who were not receiving aspirin showed a similar reaction. Furthermore, both patients and controls showed a characteristic modification of the response when aspirin was given by mouth. There can be little doubt that the abnormal response in patients with rheumatoid arthritis previously reported was due to the ingestion of aspirin.

Consideration of the effect of aspirin on the characteristics of the reaction suggests that there are two phases: an early phase of erythema, oedema, and surrounding flare, fading in $1 \frac{1}{2}$ to $2 \frac{1}{2}$ hours, and a later phase of erythema alone. Aspirin appears to exert its effect on the early phase of the reaction. It may be noted that oedema was never a feature of the late phase of the reaction.

Modification of the early phase around the site of an intradermal injection of aspirin is evidence in favour of the idea that the drug has a direct local action. The continued suppressive effect of aspirin for as long as $\mathbf{2 4}$ hours after a small dose by mouth, when it can no longer be detected in the blood, suggests fixation by the tissues.

Further work is in progress to determine whether aspirin is effective in modifying erythema or oedema induced by other agents, and whether other drugs claimed to have an anti-inflammatory action can modify the reaction to the nicotinic acid ester in a similar way.

The mode of action of this ester in producing erythema and oedema on direct application to the skin is unknown. The evidence available at present (Strehler, 1949; Oka, 1953) does not suggest that the reaction is due directly to release of histamine or that aspirin is anti-histaminic. However, it seems reasonable to suppose that the action of aspirin demonstrated in these experiments may bear a relationship to its therapeutic effect in the treatment of such conditions as rheumatic fever and rheumatoid arthritis.

\section{Summary}

(1) The characteristics of the reaction induced in normal skin by the application of the tetrahydrofurfuryl ester of nicotinic acid have been described.

(2) The reaction in patients with rheumatoid arthritis who are not receiving aspirin differs in no way from the normal.

(3) The early phase of the reaction is significantly modified in both normal and rheumatoid subjects by the administration of aspirin by mouth and by the intradermal injection of soluble aspirin before application of the ester.

(4) It is suggested that the action of aspirin demonstrated in these experiments may be related to its therapeutic effect in the treatment of diseases such as rheumatic fever and rheumatoid arthritis.

During the period when this work was done, the Rheumatic Unit was in receipt of grants from the Nuffield Foundation, the Medical Research Council, and Boots Pure Drug Company Limited.

\section{REFERENCES}

Bartfeld, H., and Hartung, E. F. (1954). Ann. rheum. Dis., 13, 70. Leifer, P., and Batterman, R. C. (1955). Amer. J. med. Sci., 230, 657 Nassim, J. R., and Banner, H. (1952). Lancet, 1, 699.

Oka, M. (1953). Acta med. scand., 145, 258.

Ropes, M. W., Bennett, G. A., Cobb, S., Jacox, R., and Jessar, R. A. (1956). Bull. rheum. Dis., 7, 121.

Smith, M. J. H. (1951). J. Pharm. Pharmacol., 3, 409.

Strehler, E. (1949). Schweiz. med. Wschr., 79, 144.

Vaillancourt, de G. (1954). Canad. med. Ass. J., 71, 283.

Effet d'aspirine sur la réponse cutanée à l'application locale d'un ester d'acide nicotinique

\section{RÉSUMÉ}

(1) On décrit les caractères de la réaction provoquée dans la peau normale par l'application de l'ester tetrahydrofurfuryl d'acide nicotinique.

(2) La réaction des malades atteints d'arthrite rhumatismale et recevant de l'aspirine ne diffère aucunément de la réaction normale.

(3) La phase précoce de la réaction se voit modifiée appréciablement chez des sujets aussi bien normaux que rhumatisants par l'administration d'aspirine par voie buccale ou par l'injection intradermique d'aspirine soluble avant l'application de l'ester.

(4) On suggère que l'action de l'aspirine mise en évidence dans ces expériences serait associée a son effet thérapeutique dans des maladies telles que le rhumatisme articulaire aigu et l'arthrite rhumatismale.

\section{Efecto de aspirina sobre la respuesta cutánea a la aplicación} local de un ester de ácido nicotinico

\section{SUMARIO}

(1) Se describen los rasgos de la reacción provocada en la piel normal por la aplicación del ester tetrahidrofurfuril de ácido nicotínico.

(2) La reacción de los enfermos con artritis reumatoide recibiendo aspirina no difiere de manera alguna de la reacción normal.

(3) La fase temprana de la reacción se ve alterada apreciadamente tanto en sujetos normales como en reumáticos por la administración de aspirina por vía oral o de aspirina soluble por vía intradérmica antes de la aplicación del ester.

(4) Se sugiere que la acción de la aspirina, evidenciada en estos experimentos, pudiera estar asociada a su efecto terapéutico en enfermedades del tipo de reumatismo poliarticular agudo o de artritis reumatoide. 